\title{
Responses of litter decomposition and nutrient release rate to water and nitrogen addition differed among three plant species dominated in a semi-arid grassland
}

\author{
Xue Wang • Zhuwen Xu • Xiaotao Lü • Ruzhen Wang • Jiangping Cai • \\ Shan Yang $\cdot$ Mai-He Li $\cdot$ Yong Jiang
}

Received: 10 January 2017 / Accepted: 11 May 2017 /Published online: 29 May 2017

(C) Springer International Publishing Switzerland 2017

\begin{abstract}
Background and aims Precipitation and nitrogen (N) deposition are predicted to increase in northern China. The present paper aimed to better understand how different dominant species in semi-arid grasslands in this region vary in their litter decomposition and nutrient release responses to increases in precipitation and $\mathrm{N}$ deposition.

Methods Above-ground litter of three dominant species (two grasses, Agropyron cristatum and Stipa krylovii,
\end{abstract}

Xue Wang and Zhuwen Xu contributed equally to this work.

Responsible Editor: Alfonso Escudero.

Electronic supplementary material The online version of this article (doi:10.1007/s11104-017-3288-8) contains supplementary material, which is available to authorized users.

X. Wang $\cdot$ Z. Xu $\cdot$ X. Lü $\cdot$ R. Wang $\cdot$ J. Cai $\cdot$ S. Yang $\cdot$ M.-H. Li $\cdot$ Y. Jiang $(\bowtie)$

Institute of Applied Ecology, Chinese Academy of Sciences, Shenyang 110016, China

e-mail: jiangyong@iae.ac.cn

X. Wang $\cdot$ M.-H. Li $(\bowtie)$

Forest Dynamics, Swiss Federal Research Institute WSL, Zuercherstrasse 111, CH-8903 Birmensdorf, Switzerland e-mail: maihe.li@wsl.ch

X. Wang $\cdot$ J. Cai

University of Chinese Academy of Sciences, Beijing 100049, China

S. Yang

College of Land and Environment, Shenyang Agricultural University, 120 Dongling Road, Shenyang 110866, China and one forb, Artemisia frigida) was collected from areas without experimental treatments in a semi-arid grassland in Inner Mongolia. Litter decomposition was studied over three years to determine the effects of water and $\mathrm{N}$ addition on litter decomposition rate and nutrient dynamics.

Results Litter mass loss and nutrient release were faster for the forb species than for the two grasses during decomposition. Both water and $\mathrm{N}$ addition increased litter mass loss of the grass A. cristatum, while the treatments showed no impacts on that of the forb A. frigida. Supplemental N had time-dependent, positive effects on litter mass loss of the grass S. krylovii. During the three-year decomposition study, the release of $\mathrm{N}$ from litter was inhibited by $\mathrm{N}$ addition for the three species, and it was promoted by water addition for the two grasses. Across all treatments, $\mathrm{N}$ and potassium (K) were released from the litter of all three species, whereas calcium (Ca) was accumulated. Phosphorus (P) and magnesium $(\mathrm{Mg})$ were released from the forb litter but accumulated in the grass litter after three years of decomposition.

Conclusions Our findings revealed that the litter decomposition response to water and $\mathrm{N}$ supplementation differed among dominant plant species in a semi-arid grassland, indicating that changes in dominant plant species induced by projected increases in precipitation and $\mathrm{N}$ deposition are likely to affect litter decomposition, nutrient cycling, and further biogeochemical cycles in this grassland. The asynchronous nutrient release of different species' litter found in the present study highlights the complexity of nutrient replenishment from 
litter decomposition in the temperate steppe under scenarios of enhancing precipitation and $\mathrm{N}$ deposition.

Keywords Litter mass loss · Nitrogen deposition . Nutrient release - Precipitation · Perennial forbs . Perennial grasses $\cdot$ Temperate steppe

\section{Introduction}

Litter decomposition is an important ecological process in global carbon (C) and nutrient cycling in terrestrial ecosystems (Berg and Laskowski 2006). There is increasing evidence that global change has important consequences for litter decomposition in diverse ecosystems (Henry and Moise 2014; Portillo-Estrada et al. 2016; Walter et al. 2013). For instance, changes in precipitation regimes could alter the rates of litter decomposition and nutrient release by affecting the activities of soil microorganisms (Schimel et al. 2007). Nitrogen (N) deposition could influence litter decomposition directly by changing the activities of soil microorganisms (Liu et al. 2010; Xu et al. 2009) and indirectly by altering litter quality (Stump and Binkley 1993). Despite the projected simultaneous increases in precipitation and $\mathrm{N}$ deposition in the temperate steppe in northern China, we lack knowledge on how water and $\mathrm{N}$ interactively influence the litter decomposition of semi-arid grassland species.

Inconsistent effects of $\mathrm{N}$ deposition on litter decomposition have been reported (Carreiro et al. 2000; Hobbie 2005; Prescott 1995), because the N effects might be modified by plant litter quality (Knorr et al. 2005), the stages of litter decomposition (Hobbie et al. 2012), and climatic factors such as precipitation. Increased soil water availability accelerates net $\mathrm{N}$ mineralization and thus improves soil $\mathrm{N}$ availability (Burke et al. 1997), with positive consequences for litter decomposition (Xiao et al. 2014). However, increases in soil water and $\mathrm{N}$ availability might have effects on litter decomposition that differ in both magnitude and direction, largely due to their contrasting influences on the soil microbial community (Ma et al. 2016; Wang et al. 2014; $\mathrm{Xu}$ et al. 2012a). For example, in a long-term water and $\mathrm{N}$ addition experiment in a semi-arid grassland, both soil microbial biomass $\mathrm{C}$ and soil microbial biomass $\mathrm{N}$ decreased with $\mathrm{N}$ addition but increased with water addition (Wang et al. 2014). Decomposition rates can also be reduced by water limitation, due to lower microbial activity and lower nutrient mobility (Bloor and Bardgett 2012). Thus, soil water availability could be a crucial factor mediating the impacts of increased $\mathrm{N}$ availability on litter decomposition (Schimel et al. 2007). Results from these earlier studies suggest that soil water and $\mathrm{N}$ may interact to influence litter decomposition, at least through their different effects on soil microorganisms, in the Inner Mongolian semi-arid grasslands, where both water and $\mathrm{N}$ are limited (Bobbink et al. 2010; Gao et al. 2008). However, experimental investigations from that semi-arid region are lacking.

Another aspect that should be considered is whether different species in that semi-arid grassland differ in their decomposition responses to increasing water and $\mathrm{N}$ availability. Previous studies have indicated that plant species differ in their rates of litter decomposition because of interspecific litter chemical composition, such as concentrations of nutrients and organic compounds (Carpita 1996; Manning et al. 2008; Smith and Bradford 2003). For example, the difference in litter decomposition rate between grasses and forbs has been reported at the regional (Koukoura et al. 2003; Zhu et al. 2016) and global scale (Cornwell et al. 2008). Different plant species respond differently in their litter decomposition rates to environmental changes such as water addition (Liu et al. 2006; Schuster 2016) and $\mathrm{N}$ addition (Hobbie 2008; Li et al. 2011) in grassland ecosystems. Overall, these differences in decomposition will inevitably influence the rate and amount of the release of multiple nutrients from litter (Hobbie 1996; Seastedt 1984), and subsequently influence the ecosystem productivity by changing soil nutrient availability and nutrient limitation status (Fay et al. 2015).

In the present study, we examined the interactive effects of plant species, water, and nitrogen on litter decomposition in semi-arid grasslands of northern China (Inner Mongolia), where both water and $\mathrm{N}$ are limited (Bai et al. 2010; Niu et al. 2008) but annual precipitation (Feng et al. 2011; Gao et al. 2008) and atmospheric N deposition (Bobbink et al. 2010; Liu et al. 2011) are expected to continue to increase. We aimed to answer whether and how different dominant species differ in their litter decomposition rate and nutrient release in response to increased soil water and $\mathrm{N}$ availability in a semi-arid grassland in northern China. This knowledge will help us better understand and manage semi-arid grassland ecosystems in a changing world. 


\section{Materials and methods}

Study site and experimental design

The study site $\left(116^{\circ} 17^{\prime} \mathrm{E}\right.$ and $42^{\circ} 02^{\prime} \mathrm{N}$, elevation $1324 \mathrm{~m}$ a.s.l.) is located in Duolun County, a semi-arid area in Inner Mongolia, China. Mean annual precipitation is $379 \mathrm{~mm}$ and mean annual temperature is $2.1^{\circ} \mathrm{C}$, with mean monthly temperatures ranging from $-17.5^{\circ} \mathrm{C}$ in January to $18.9^{\circ} \mathrm{C}$ in July. The growing season for the plant community is from April to October. Dominant plant species in the studied grassland include one forb species, Artemisia frigida Willd., and two grass species, Agropyron cristatum (L.) Gaertn. and Stipa krylovii Roshev, which account for $30.6 \%, 15.9 \%$ and $12.6 \%$ of the total community aboveground biomass, respectively (Xu et al. 2010). At the beginning of the present study, the three species had a mean total coverage of $41 \%$ and the grassland community had a mean total plant cover of $65 \%$. Leaves of the two grass species Agropyron cristatum and Stipa krylovii are completely yellow by the middle of September, and the forb Artemisia frigida is one month later. The soil type is chestnut according to Chinese classification or Calcis-orthic Aridisol according to the US Soil Taxonomy classification (Xu et al. 2012b).

The experiment followed a split-plot experimental design with a replication of seven blocks. Each block $(107 \mathrm{~m} \times 8 \mathrm{~m})$ was divided into two main plots for water treatments (ambient precipitation and water addition). Each main plot was divided into six $8 \mathrm{~m} \times$ $8 \mathrm{~m}$ subplots. Each of the six subplots was randomly assigned to no nutrient addition or treatment with 5 , 10 or $15 \mathrm{~g} \mathrm{~N} \mathrm{~m}^{-2} \mathrm{yr}^{-1}, 10 \mathrm{~g} \mathrm{P} \mathrm{m}^{-2} \mathrm{yr}^{-1}$, or the combination of $10 \mathrm{~g} \mathrm{~N}+10 \mathrm{~g} \mathrm{P} \mathrm{m}^{-2} \mathrm{yr}^{-1}$. The water addition plots received $15 \mathrm{~mm}$ of additional water weekly by sprinkling irrigation during the growing season between June and August (a total of $180 \mathrm{~mm}$ of additional water, approximately $+50 \%$ of the annul natural rainfall) starting in 2005. Nitrogen (urea) and P (superphosphate) were applied to subplots, half in early May and the other half in late June, every year starting in 2005 (Xu et al. 2012b).

\section{Litter decomposition experiment}

Four of the treatments listed above, i.e. control (C), $10 \mathrm{~g}$ $\mathrm{N} \mathrm{m}^{-2} \mathrm{yr}^{-1}(\mathrm{~N})$, water addition $(\mathrm{W})$, and combined water and $\mathrm{N}\left(10 \mathrm{~g} \mathrm{~N} \mathrm{~m}^{-2} \mathrm{yr}^{-1}\right)$ addition $(\mathrm{WN})$, were used in the present study. In late October 2011, the senescent above-ground tissues still attached to the three dominant species, including two bunchgrasses (Agropyron cristatum, Stipa krylovii) and one forb species (Artemisia frigida), were collected in non-treated grassland outside the experimental blocks. After airdrying the material until a constant mass was reached, $15 \mathrm{~g}$ litter of each species was placed into a separate $25 \mathrm{~cm} \times 20 \mathrm{~cm}$ polyethylene litterbag (mesh size $1 \mathrm{~mm}$ ). The litterbags were then placed in the treatment plots mentioned above. A total of 252 litterbags (3 plant species $\times 4$ treatments $\times 7$ replicates $\times 3$ sampling dates) were fixed to the ground surface with metal pins to prevent movement caused by wind. Ten sub-samples of litter of each species were oven-dried at $70{ }^{\circ} \mathrm{C}$ for $48 \mathrm{~h}$ at the time of initial deployment to determine the ratio between air-dried mass and oven-dried mass, which was used to convert the initial air-dried mass of litter into oven-dried mass. Litterbags were retrieved 1, 2 , and 3 years after the initial deployment. The visible animals (e.g. earthworms, mature insects and larvae of insects) and extraneous mineral matter were removed from the litter residues. The retrieved litter samples were then oven-dried at $70{ }^{\circ} \mathrm{C}$ for $48 \mathrm{~h}$ to determine the remaining dry mass.

\section{Chemical analysis}

Concentrations of elements $(\mathrm{C}, \mathrm{N}, \mathrm{P}, \mathrm{K}, \mathrm{Ca}, \mathrm{Mg})$ and non-structural carbohydrates (NSC) were analyzed for initial litter and litter during the decomposition process. After determining the dry mass, litter of each plant species was ground to pass a 100 mesh size for chemical analysis. Total $\mathrm{C}$ and $\mathrm{N}$ concentrations of samples were analyzed using a $\mathrm{C} / \mathrm{N}$ analyzer (Vario Micro cube, Germany). Total P concentrations were determined following the ammonium molybdate method after nitric acid and perchloric acid (2:1) digestion (Kuo 1996). The concentrations of $\mathrm{K}$, $\mathrm{Ca}$ and $\mathrm{Mg}$ were determined using an atomic absorption spectrophotometer (AA6800, Shimadzu, Japan) after digestion in a mixture of nitric and perchloric acids. NSC is defined here as the sum of soluble sugars and starch ( $\mathrm{Li}$ et al. 2002). NSC was determined spectrophotometrically (ultravioletvisible spectrophotometer 752S, Cany Precision Instruments Co., Ltd., Shanghai, China) at $620 \mathrm{~nm}$ using the anthrone method, as described in detail in Li et al. (2013). 
Statistical analysis

The normality of the distribution and the homogeneity of the data were checked (Kolmogorov-Smirnov-Test) before any statistical analyses. Data that did not meet this condition were log/sqrt-transformed prior to analyses to normalize their distributions. The mass loss rate ((1-final dry mass/initial dry mass $) \times 100 \%)$ or nutrient release ((1-final nutrient content/initial nutrient content) $\times 100 \%$ ) were calculated as the amount of litter mass or nutrients lost as a percent of the total initial litter mass or nutrient concentration (Baker et al. 2001). Four-way ANOVAs with a split-plot design were employed to test the effects of water, nitrogen, species, time, and their interactions on mass loss and nutrient release from litter. Significant differences among species identities and sampling times were found for all parameters; therefore, we additionally used three-way ANOVAs with a splitplot design to test the effects of water, nitrogen, time and their interactions on litter mass loss and nutrient release for each species separately. Two-way ANOVAs with a split-plot design were used to explore the responses of mass loss and nutrient release to water and $\mathrm{N}$ addition for each species on each sampling date. One-way ANOVAs with Duncan's multiple range tests were used for comparisons of initial litter chemistry among different plant species with a significance level of $P<0.05$. Data analyses were performed using procedures in SPSS 16.0 (SPSS, Inc., Chicago, IL, U.S.A.).

\section{Results}

Initial litter chemistry

Out of the three species investigated, the forb A. frigida had the highest initial concentrations of C, N, P, K, Ca and $\mathrm{Mg}$ (all $P<0.05$, Table 1). Similar $\mathrm{N}$ levels for
A. frigida and S. krylovii was an exception. The two grasses, A. cristatum and S. krylovii, had similar P, K, Ca and $\mathrm{Mg}$ concentrations, but the latter had higher levels of $\mathrm{C}$ and $\mathrm{N}$ than the former (both $P<0.05$, Table 1). The initial $\mathrm{C} / \mathrm{N}$ ratio of $A$. cristatum litter was much higher than that of A. frigida and S. krylovii litter $(P<0.05$, Table 1).

\section{Mass and NSC loss}

Dry mass loss of litter significantly differed among plant species and decomposition times (both $P<0.001$, Table 2, Fig. 1a-c). After the three-year decomposition period, on average across the treatments, the mass loss did not differ between S. krylovii (46.9\%) and A. cristatum $(43.4 \%)$, but it was significantly higher for A. frigida (51.2\%) $(P<0.05$, Fig. 1a-c). Water addition significantly increased litter mass loss across all the species and times $(P=0.016$, Table 2$)$, though the effect varied among species (significant interaction between water treatment and species, $P=0.003$, Table 2). Water addition increased the mass loss of $A$. cristatum litter, by $58.6 \%$ after one year, $37.4 \%$ after two years and $16.1 \%$ after three years (Fig. 1a), but did not affect mass loss of S. krylovii and A. frigida litter (Fig. 1b-c). Nitrogen addition increased the mass loss of litter $(P<0.001$, Table 1$)$, with a significant effect for A. cristatum $(P=0.001)$ and $S$. krylovii $(P=0.007)$ and a marginally significant effect for $A$. frigida ( $P=0.061$; Table S1, Fig. 1a-c). Across the three species and times, there was no significant interactive effect between water and $\mathrm{N}$ addition treatment on litter mass loss $(P=0.087$, Table 2).

Non-structural carbohydrates (NSC), the labile components of litter mass, responded significantly to $\mathrm{N}$ addition and plant species (both $P<0.001$, Table 2). Nitrogen addition significantly promoted the loss of NSC for litter of all three species (all $P<0.001$, Table 2,

Table 1 Initial nutrient concentrations in litters of Agropyron cristatum, Stipa krylovii and Artemisia frigida

\begin{tabular}{llllllll}
\hline Species & $\mathrm{C}(\mathrm{mg} / \mathrm{g})$ & $\mathrm{N}(\mathrm{mg} / \mathrm{g})$ & $\mathrm{P}(\mathrm{mg} / \mathrm{g})$ & $\mathrm{K}(\mathrm{mg} / \mathrm{g})$ & $\mathrm{Ca}(\mathrm{mg} / \mathrm{g})$ & $\mathrm{Mg}(\mathrm{mg} / \mathrm{g})$ & $\mathrm{C} / \mathrm{N} \mathrm{ratio}$ \\
\hline A.cristatum & $444.73 \pm 0.72 \mathrm{c}$ & $6.29 \pm 0.15 \mathrm{~b}$ & $0.29 \pm 0.02 \mathrm{~b}$ & $2.70 \pm 0.10 \mathrm{~b}$ & $2.32 \pm 0.18 \mathrm{~b}$ & $0.42 \pm 0.02 \mathrm{~b}$ & $70.98 \pm 1.64 \mathrm{a}$ \\
S. krylovii & $450.14 \pm 0.64 \mathrm{~b}$ & $8.89 \pm 026 \mathrm{a}$ & $0.33 \pm 0.02 \mathrm{~b}$ & $3.06 \pm 0.15 \mathrm{~b}$ & $2.56 \pm 0.11 \mathrm{~b}$ & $0.59 \pm 0.01 \mathrm{~b}$ & $50.91 \pm 1.58 \mathrm{~b}$ \\
A. frigida & $460.87 \pm 0.75 \mathrm{a}$ & $8.78 \pm 0.23 \mathrm{a}$ & $0.90 \pm 0.03 \mathrm{a}$ & $8.46 \pm 0.14 \mathrm{a}$ & $4.20 \pm 0.16 \mathrm{a}$ & $0.99 \pm 0.03 \mathrm{a}$ & $52.72 \pm 1.32 \mathrm{~b}$ \\
\hline
\end{tabular}

Mean values ( $\pm 1 \mathrm{SE}, n=7)$ are given. Different letters within a single column indicate significant differences among the three species at $P<0.05$ 


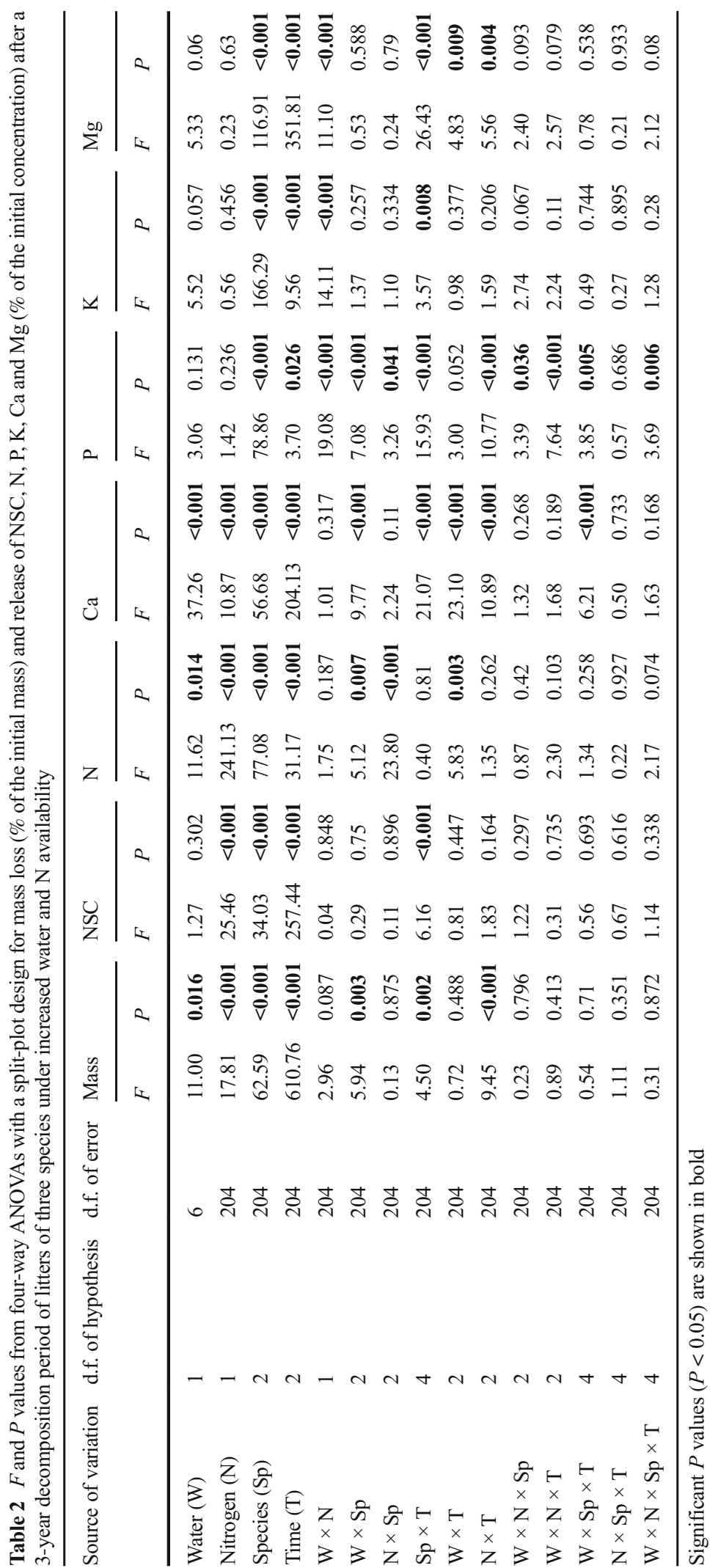




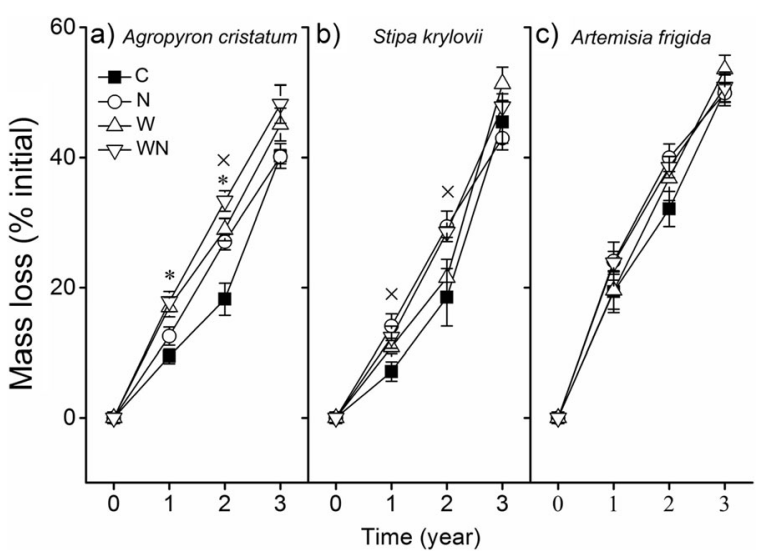

Fig. 1 Effects of water and $\mathrm{N}$ addition on the mass loss rate of Agropyron cristatum, Stipa krylovii and Artemisia frigida litter during a 3-year decomposition period. Vertical bars represent standard errors $(n=7)$. Squares, control $(C)$; circles, addition of $10 \mathrm{~g} \mathrm{~N} \mathrm{~m}^{-2}$ yr. $^{-1}(\mathrm{~N})$; regular triangles, water addition $(\mathrm{W})$; inverted triangles, water plus nitrogen addition (WN). Results of two-way ANOVAs with a split-plot design for each sampling date are shown. The symbols $*$ and $\times$ indicate significant $(P<0.05)$ main effects of water and nitrogen addition, respectively

Fig. 2a-c). No significant effects of water addition on NSC loss were detected $(P=0.302$, Table 2$)$. The loss of NSC occurred rapidly during the first two years of decomposition, with $\sim 80 \%$ of initial litter NSC lost for each species (Fig. 2a-c). However, NSC loss was much slower during the third year, with less than $10 \%$ of the

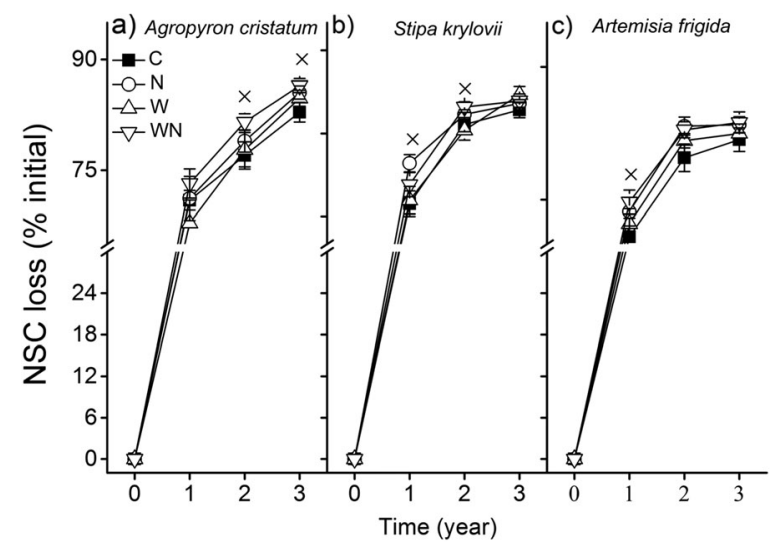

Fig. 2 Effects of water and $\mathrm{N}$ addition on the loss of nonstructural carbohydrates (NSC) from Agropyron cristatum, Stipa krylovii and Artemisia frigida litter during a 3-year decomposition period. Squares, control (C); circles, addition of $10 \mathrm{~g} \mathrm{~N} \mathrm{~m}^{-2} \mathrm{yr}^{-1}$ $(\mathrm{N})$; regular triangles, water addition $(\mathrm{W})$; inverted triangles, water plus nitrogen addition (WN). Vertical bars represent standard errors $(n=7)$. Results of two-way ANOVAs with a split-plot design for each sampling date are shown. The symbols $*$ and $\times$ indicate significant $(P<0.05)$ main effects of water and nitrogen addition, respectively initial litter NSC lost for each of the three species (Fig. 2a-c).

Nutrient concentrations

The concentrations of $\mathrm{N}, \mathrm{Mg}$ and $\mathrm{Ca}$ increased over time for litter from each of the three species. Phosphorus concentrations increased over time in A. cristatum and S. krylovi litter but decreased in A. frigida litter (Fig. 3). The concentrations of $\mathrm{K}$ decreased quickly for $A$. frigida litter but were relatively stable for A. cristatum and S. krylovi litter over the three years of decomposition (Fig. 3g-i). Nitrogen addition consistently increased N concentrations in litter of all three species (all $P<0.001$, Fig. 3a-c), while water addition decreased $\mathrm{N}$ concentrations in litter of the two grasses during the decomposition process $(P=0.011$ and 0.033 , respectively, Fig. 3a-b). The concentrations of $\mathrm{Ca}$ in A. cristatum and S. krylovii litters increased with water addition (by $115.5 \%$ and $54.5 \%$, respectively, both $P<0.001$ ) and $\mathrm{N}$ addition (by $34.6 \%$ and $19.4 \%$, respectively, both $P<0.01$ ) after three years of decomposition (Fig. 3m-n). Artemisia frigida litter nutrient concentrations were less sensitive to treatments, except that $\mathrm{N}$ concentration was affected by $\mathrm{N}$ addition $(P<0.001$, Fig. $3 c)$.

Nutrient release and immobilization

Both water and $\mathrm{N}$ addition significantly affected the $\mathrm{N}$ and Ca release from litter (all $P<0.05$, Table 2). However, neither water nor $\mathrm{N}$ addition affected the $\mathrm{P}, \mathrm{K}$ and $\mathrm{Mg}$ release from litter (all $P>0.05$, Table 2). Species identity interacted significantly with water or $\mathrm{N}$ addition to affect $\mathrm{N}, \mathrm{Ca}$ and $\mathrm{P}$ release from litter (all $P<0.01$, Table 2), except there was not a significant interactive effect between $\mathrm{N}$ addition and species on $\mathrm{Ca}$ release $(P=0.11$, Table 2). Nitrogen addition inhibited litter $\mathrm{N}$ release for all three species after three years of decomposition, by $139.3 \%$ for A. cristatum, $84.9 \%$ for S. krylovii and $34.8 \%$ for $A$. frigida (all $P<0.001$, Table S1). Both water and $\mathrm{N}$ addition inhibited litter Ca release for the two grasses, by $234.9 \%$ and $55.3 \%$, respectively, for A. cristatum, and by $83.3 \%$ and $49.3 \%$, respectively, for $S$. krylovii (all $P<0.05$, Table S1, Fig. $4 \mathrm{~m}-\mathrm{n}$ ), but neither water nor $\mathrm{N}$ addition had a significant effect on $\mathrm{Ca}$ release for the forb litter $(P=0.196$ and 0.625 , respectively, Table S1, Fig. 4o). There were significant interactive effects between water and $\mathrm{N}$ addition on the $\mathrm{P}, \mathrm{K}$ and $\mathrm{Mg}$ release from the 


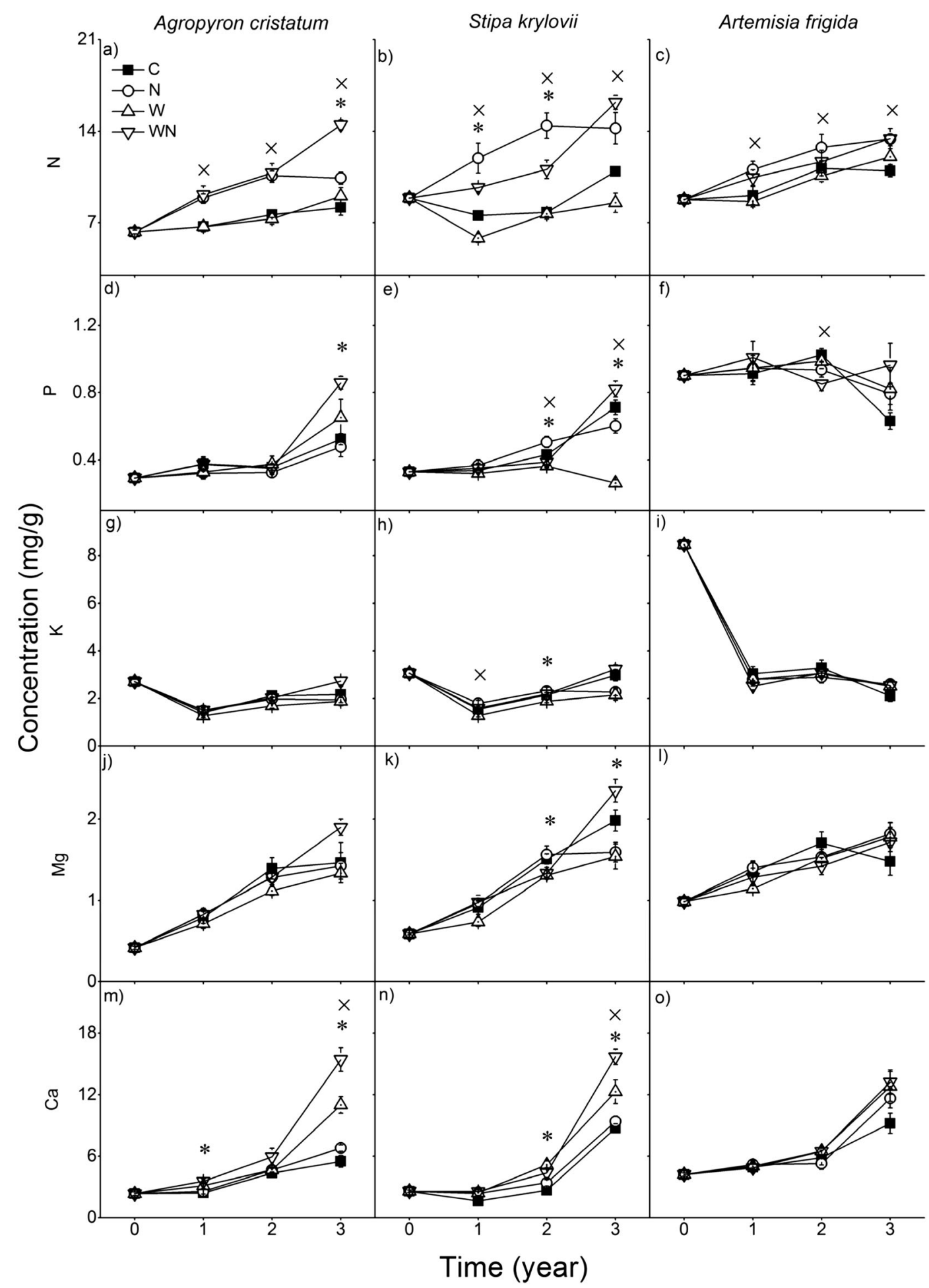

Fig. 3 Effects of water and $\mathrm{N}$ addition on the concentrations of N, $\mathrm{P}, \mathrm{K}, \mathrm{Ca}$ and $\mathrm{Mg}$ in Agropyron cristatum, Stipa krylovii and Artemisia frigida litter during a 3-year decomposition period. Squares, control (C); circles, addition of $10 \mathrm{~g} \mathrm{~N} \mathrm{~m}^{-2} \mathrm{yr}^{-1}(\mathrm{~N})$; regular triangles, water addition (W); inverted triangles, water plus nitrogen addition $(\mathrm{WN})$. Vertical bars represent standard errors $(n=7)$. The symbols $*$ and $\times$ indicate significant $(P<0.05)$ main effects of water and nitrogen addition, respectively 


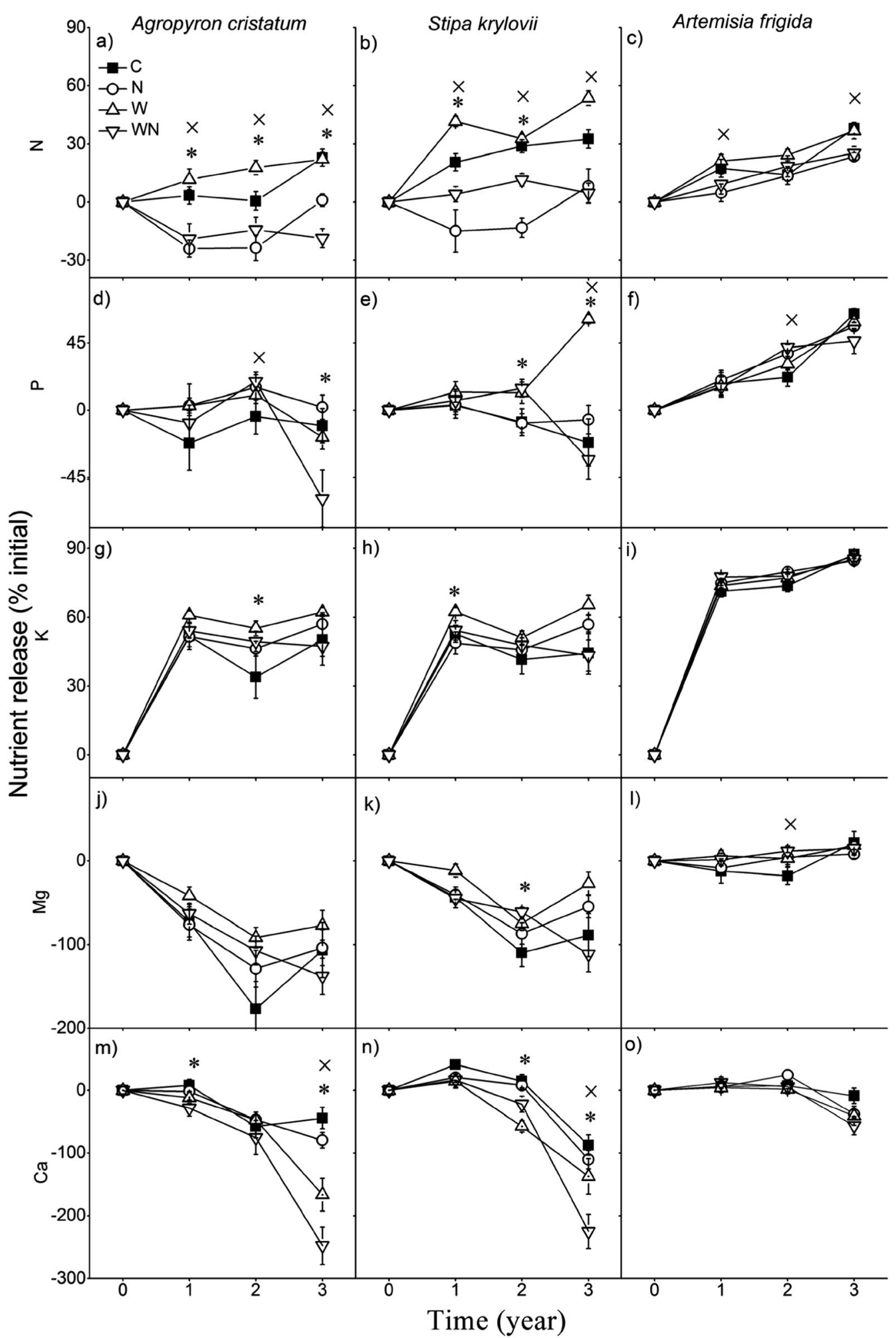

Fig. 4 Effects of water and $\mathrm{N}$ addition on the release of N, P, K, $\mathrm{Ca}$ and $\mathrm{Mg}$ in Agropyron cristatum, Stipa krylovii and Artemisia frigida litter during a 3-year decomposition period. Squares, control $(\mathrm{C})$; circles, addition of $10 \mathrm{~g} \mathrm{~N} \mathrm{~m}^{-2} \mathrm{yr}^{-1}(\mathrm{~N})$; regular triangles, water addition $(\mathrm{W})$; inverted triangles, water plus nitrogen addition $(\mathrm{WN})$. Vertical bars represent standard errors $(n=7)$. The symbols $*$ and $\times$ indicate significant $(P<0.05)$ main effects of water and nitrogen, respectively 
litters (all $P<0.001$, Table 2). Significant interactive effects between species identity and time on nutrient release were found (all $P<0.01$, Table 2), except for the case of $\mathrm{N}$ release $(P=0.81$, Table 2$)$.

Nutrient release from litter differed significantly among plant species and times (all $P<0.001$, Table 2). After three years of decomposition, the nutrient release from the forb litter $A$. frigida was faster than that from the two grass litters (all $P<0.05$, Fig. 5). Across all treatments, $\mathrm{N}$ and $\mathrm{K}$ of litter from the three species were released over time; in contrast, $\mathrm{Ca}$ was immobilized during the three-year decomposition study (Fig. 5). Both $\mathrm{P}$ and $\mathrm{Mg}$ were immobilized over time for $A$. cristatum and $S$. krylovii litter, whereas they were released over time for A. frigida (Fig. 5).

\section{Discussion}

Interspecific differences in mass loss and nutrient release

Our results clearly showed that there were significant discrepancies in litter mass loss and nutrient release among the three species across the environmental treatments and decomposition duration (time). Significantly more mass loss and nutrient release were found for litter of the forb A. frigida compared with litter of two grasses (Figs. 1 and 5), which is in line with the finding from a meta-analysis that forbs decompose much faster than graminoids (Cornwell et al. 2008) because of higher nutrient concentrations. In general, the initial $\mathrm{N}$ concentration and $\mathrm{C} / \mathrm{N}$ ratio have been considered as the major factors controlling litter decomposition (Aerts 1997; Cornwell et al. 2008). In our study, the faster mass loss of $A$. frigida litter than that of $A$. cristatum litter could be attributed to the higher $\mathrm{N}$ level and lower $\mathrm{C} / \mathrm{N}$ ratio of A. frigida (Table 1). However, this was not the case for A. frigida and S. krylovii (the similar N level, Table 1) where higher concentrations of other nutrients (such as $\mathrm{P}, \mathrm{K}, \mathrm{Ca}$ and $\mathrm{Mg}$, Table 1) contributed to the faster mass loss of $A$. frigida litter. This is in line with previous findings that multiple litter macronutrients play a prominent role in regulating litter decomposition, for example litter $\mathrm{Ca}$ and $\mathrm{Mg}$ (Makkonen et al. 2012) and P, K, Ca and $\mathrm{Mg}$ (Yue et al. 2016) in forest ecosystems, litter $\mathrm{Ca}$ and $\mathrm{Mg}$ in two ecosystems across five biomes (GarcíaPalacios et al. 2016), and litter N, P, K, Ca and Mg on a global scale (Zhang et al. 2008). In addition, A. cristatum and S. krylovii, which contain more fibrous structural elements, decomposed much slower than A. frigida. Plant species control their litter decomposition rate by changing both the quality and the amount of litter. In the present study, the three species studied together account for $59 \%$ of the total aboveground biomass and $63 \%$ of the total aboveground cover in this ecosystem. Therefore, the variation in decomposition rate among the three dominant species highlights the role of species identity in driving litter decomposition and nutrient cycles in this semi-arid grassland.
Fig. 5 The release of N, P, K, Ca and $\mathrm{Mg}$ from Agropyron cristatum, Stipa krylovii and Artemisia frigida litter during a 3year decomposition period. Each data point represents the average over all treatments. Values (Mean $\pm \mathrm{SE}, n=7$ ) with different letters are significantly different $(P<0.05)$

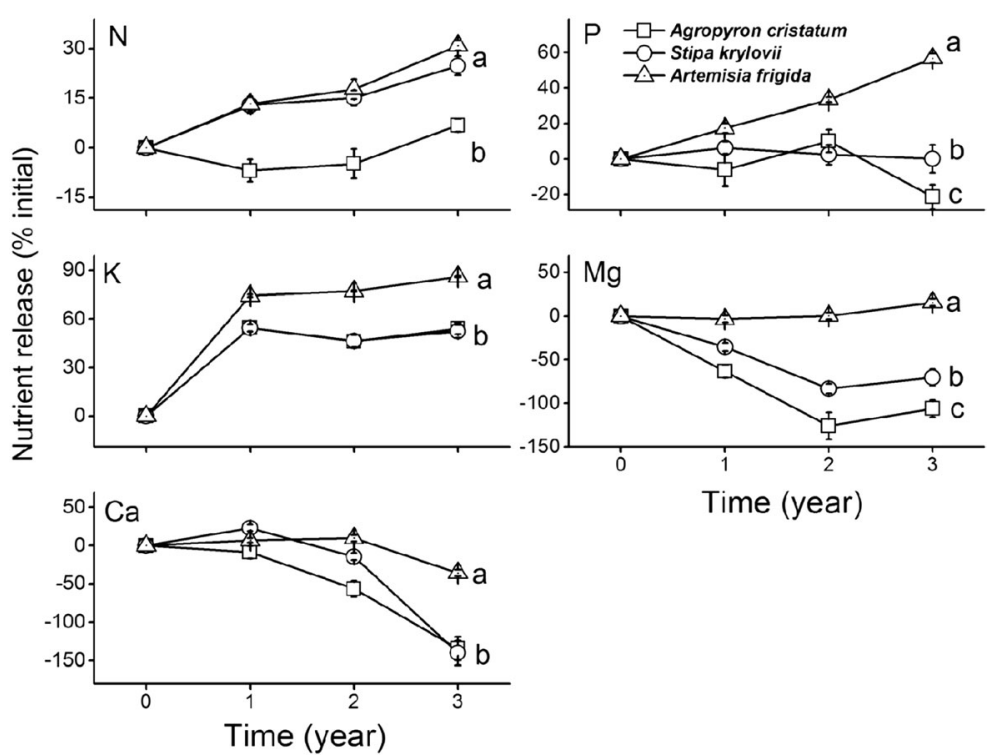


Interspecific response of mass loss to water and $\mathrm{N}$ addition

Water and $\mathrm{N}$ addition were expected to accelerate litter decomposition by supplying soil microbes with more soil water (increased by $30.4 \%$, data not shown) and soil inorganic $\mathrm{N}$ (increased by $21.7 \%$, data not shown) in this semi-arid grassland. In our study, significant increases in $\mathrm{N}$ concentration for litter from all three plant species were found under $\mathrm{N}$ addition, and the mass loss was stimulated significantly by water and $\mathrm{N}$ addition (Table 2; Fig. 1). In contrast to our results, most previous studies showed that litter decomposition was negatively influenced by $\mathrm{N}$ addition due to the suppression of ligninolytic enzymes (Carreiro et al. 2000; Hobbie et al. 2012). Indeed, another study carried out at the same experimental site in the year 2013 (the second year of our litter decomposition experiment) showed that activities of the main lignin-decomposing enzymes, such as polyphenol oxidase $(-23.8 \%)$ and peroxidase $(-26.6 \%)$ were significantly decreased by $\mathrm{N}$ addition (Yang S, unpublished data), which might negatively influence the mass loss rate at later decomposition stages. In this study, however, litter decomposition was at the early to middle stage of the whole litter decomposition process because the mean mass loss across all three litters was only $24.5 \%$ to $36.8 \%$ after two years, and $43.4 \%$ to $51.2 \%$ after three years of decomposition. The early stages of litter decomposition could be accelerated by $\mathrm{N}$ deposition due to high concentrations of labile carbohydrates relative to $\mathrm{N}$ concentrations (Berg and Matzner 1997). In our study, most labile components (almost $80 \%$ ) of the initial NSC were decomposed within the first two years (Fig. 2), indicating that the initial NSC could meet the C demand of soil microbes. Additionally, the absence of water or $\mathrm{N}$ effects on litter mass and NSC loss in the third year of decomposition might imply the start of recalcitrant compound decomposition. Moreover, environmental variables such as increased water and $\mathrm{N}$ availability may have little influence on the decomposition of recalcitrant components, which is consistent with findings from a previous study that significant warming and $\mathrm{N}$ addition effects on Bromus inermis and Poa pratensis mass loss were observed within the first years of treatment but disappeared thereafter in an old-field grassland (Henry and Moise 2014).

In the present study, litter mass loss for A. cristatum and $S$. krylovii was more sensitive to water and $\mathrm{N}$ addition than that for A. frigida, indicating that environmental factors might have a small effect on the decomposition of litter with higher quality. Similarly, results from a meta-analysis showed that the responses of litter decomposition to $\mathrm{N}$ deposition might be partly regulated by litter quality (Knorr et al. 2005). Furthermore, such divergent responses at the inter-specific level might highlight the joint role of environmental factors, litter quality and soil microorganisms in determining litter decomposition. Additionally, the mass loss of litter from A. frigida is faster than that of litter from A. cristatum and $S$. krylovii. Our previous studies in the same experiment showed that increases in water and $\mathrm{N}$ availability could change species composition of the plant community, and the dominant species contributed the most to such changes (Xu et al. 2012b, c). Together, these findings suggest that changes in precipitation and $\mathrm{N}$ deposition may strongly alter nutrient replenishment from litter decomposition and biogeochemical cycles in this semi-arid grassland by changing species composition.

The asynchrony of nutrient release

We found unsynchronized nutrient release during the three-year decomposition period, with the most rapid loss for $\mathrm{K}$, followed by $\mathrm{N}, \mathrm{P}$ and $\mathrm{Mg}$, and the most accumulation of $\mathrm{Ca}$ (Fig. 5). A potential implication underlying this unsynchronized release is the conversion from single-element limitation to multi-nutrient limitation for plant growth, which has already been proposed elsewhere (Chapin et al. 1986; Fornara et al. 2013; Fay et al. 2015).

The increased $\mathrm{N}$ release from the litter of grasses following water addition indicates that increases in precipitation contribute to rapid soil $\mathrm{N}$ replenishment. On the other hand, water addition could also increase the risk of soil $\mathrm{N}$ loss by leaching. Water addition significantly increased $\mathrm{Ca}$ immobilization in grass litter, which may be attributed to increased soil $\mathrm{Ca}$ concentration $(+39 \%)$ by water addition in this semi-arid grassland (Cai JP, unpublished data) and to the strong demand of soil microbes to decompose recalcitrant compounds, since the initial $\mathrm{Ca}$ concentrations were lower for the litter of grasses than for forb litter. However, the release of $\mathrm{P}, \mathrm{K}$ and $\mathrm{Mg}$ was less sensitive to the environmental changes. The variable response of nutrient release $(\mathrm{N}, \mathrm{P}$, $\mathrm{K}, \mathrm{Mg}$ and $\mathrm{Ca}$ ) to increased water and $\mathrm{N}$ availability during decomposition could have important consequences for soil nutrient supply and therefore for the 
nutrient availability for plants. Our results thus suggest that long-term increases in precipitation and $\mathrm{N}$ deposition are likely to lead to changes in soil nutrient supply and availability due to an asynchrony of nutrient release of different species' litter in this semi-arid grassland. For example, our previous findings in the same experiment site showed that long-term $\mathrm{N}$ addition could result in nutrient limitation conversion from $\mathrm{N}$ limitation to $\mathrm{P}$ limitation for the two grasses A. cristatum and S. krylovii (Wang et al. 2017).

\section{Conclusions}

We found that litter decomposition and its responses to increases in water and $\mathrm{N}$ availability varied greatly across the three dominant species in the semi-arid grassland. The slower mass loss and nutrient release of A. cristatum and S. krylovii litter suggest their potential role in maintaining the long-term soil nutrient supply. The faster mass loss and nutrient release of $A$. frigida litter indicate the importance of this species in quickly replenishing soil nutrients, but it may also increase the risk of nutrient loss from its litter. The different magnitude of the responses of litter from the three dominant species to environmental variations indicates that the changes in species composition induced by global changes might indirectly impact biogeochemical cycles in this semi-arid grassland. Our results also highlight the need for long-term studies to deepen our understanding of general patterns of litter decomposition processes under global change.

Acknowledgements We thank the staff of the Duolun Restoration Ecological Research Station for facilitating this study, and Melissa Dawes for the language correction. This work was supported by the National Key Research and Development Program of China (2016YFC0500707), the National Natural Science Foundation of China (41371251, 31370009, 41371076), the Youth Innovation Promotion Association CAS (2014174), and the Sino-Swiss Science and Technology Cooperation (SSSTC) program (Project No. EG 06-032015).

\section{References}

Aerts R (1997) Climate, leaf litter chemistry and leaf litter decomposition in terrestrial ecosystems: a triangular relationship. Oikos 79:439-449

Bai Y, Wu J, Clark CM, Naeem S, Pan Q, Huang J, Zhang L, Han X (2010) Tradeoffs and thresholds in the effects of nitrogen addition on biodiversity and ecosystem functioning: evidence from inner Mongolia grasslands. Glob Change Biol 16:358-372

Baker TT, Lockaby BG, Conner WH, Meier CE, Stanturf JA, Burke MK (2001) Leaf litter decomposition and nutrient dynamics in four southern forested floodplain communities. Soil Sci Soc Am J 65:1334-1347

Berg B, Laskowski R (2006) Litter decomposition: a guide to carbon and nutrient turnover. Academic Press, Amsterdam

Berg B, Matzner E (1997) Effect of N deposition on decomposition of plant litter and soil organic matter in forest systems. Environ Rev 5:1-25

Bloor JMG, Bardgett RD (2012) Stability of above-ground and below-ground processes to extreme drought in model grassland ecosystems: interactions with plant species diversity and soil nitrogen availability. Perspect Plant Ecol 14:193-204

Bobbink R, Hicks K, Galloway J, Spranger T, Alkemade R, Ashmore M, Bustamante M, Cinderby S, Davidson E, Dentener F (2010) Global assessment of nitrogen deposition effects on terrestrial plant diversity: a synthesis. Ecol Appl 20:30-59

Burke IC, Lauenroth WK, Parton WJ (1997) Regional and temporal variation in net primary production and nitrogen mineralization in grasslands. Ecology 78:1330-1340

Carpita NC (1996) Structure and biogenesis of the cell walls of grasses. Annu Rev Plant Physiol Plant Mol Biol 47:445-476

Carreiro M, Sinsabaugh R, Repert D, Parkhurst D (2000) Microbial enzyme shifts explain litter decay responses to simulated nitrogen deposition. Ecology 81:2359-2365

Chapin FS, Vitousek PM, Van Cleve K (1986) The nature of nutrient limitation in plant communities. Am Nat 127:48-58

Cornwell WK, Cornelissen JHC, Amatangelo K, Dorrepaal E, Eviner VT, Godoy O, Hobbie SE, Hoorens B, Kurokawa H, Pérez-Harguindeguy N, Quested HM, Santiago LS, Wardle DA, Wright IJ, Aerts R, Allison SD, van Bodegom P, Brovkin V, Chatain A, Callaghan TV, Díaz S, Garnier E, Gurvich DE, Kazakou E, Klein JA, Read J, Reich PB, Soudzilovskaia NA, Vaieretti MV, Westoby M (2008) Plant species traits are the predominant control on litter decomposition rates within biomes worldwide. Ecol Lett 11:1065-1071

Fay PA, Prober SM, Harpole WS, Knops JMH, Bakker JD, Borer ET, Lind EM, MacDougall AS, Seabloom EW, Wragg PD, Adler PB, Blumenthal DM, Buckley Y, Chu C, Cleland EE, Collins SL, Davies KF, Du G, Feng X, Firn J, Gruner DS, Hagenah N, Hautier Y, Heckman RW, Jin VL, Kirkman KP, Klein J, Ladwig LM, Li Q, McCulley RL, Melbourne BA, Mitchell CE, Moore JL, Morgan JW, Risch AC, Schuetz M, Stevens CJ, Wedin DA, Yang LH (2015) Grassland productivity limited by multiple nutrients. Nat Plants 1:15080

Feng L, Zhou TJ, Wu B, Li T, Luo JJ (2011) Projection of future precipitation change over China with a high-resolution global atmospheric model. Adv Atmos Sci 28:464-476

Fornara DA, Banin L, Crawley MJ (2013) Multi-nutrient vs. nitrogen-only effects on carbon sequestration in grassland soils. Glob Change Biol 19:3848-3857

Gao X, Shi Y, Song R, Giorgi F, Wang Y, Zhang D (2008) Reduction of future monsoon precipitation over China: comparison between a high resolution RCM simulation and the driving GCM. Meteorog Atmos Phys 100:73-86 
García-Palacios P, McKie BG, Handa IT, Frainer A, Hättenschwiler S, Jones H (2016) The importance of litter traits and decomposers for litter decomposition: a comparison of aquatic and terrestrial ecosystems within and across biomes. Funct Ecol 30:819-829

Henry HAL, Moise ERD (2014) Grass litter responses to warming and $\mathrm{N}$ addition: temporal variation in the contributions of litter quality and environmental effects to decomposition. Plant Soil 389:35-43

Hobbie SE (1996) Temperature and plant species control over litter decomposition in Alaskan tundra. Ecol Monogr 66: $503-522$

Hobbie SE (2005) Contrasting effects of substrate and fertilizer nitrogen on the early stages of decomposition. Ecosystems 8: 644-656

Hobbie SE (2008) Nitrogen effects on decomposition: a five-year experiment in eight temperate sites. Ecology 89:2633-2644

Hobbie SE, Eddy WC, Buyarski CR, Adair EC, Ogdahl ML, Weisenhorn P (2012) Response of decomposing litter and its microbial community to multiple forms of nitrogen enrichment. Ecol Monogr 82:389-405

Knorr M, Frey SD, Curtis PS (2005) Nitrogen additions and litter decomposition: a meta-analysis. Ecology 86:3252-3257

Koukoura Z, Mamolos AP, Kalburtji KL (2003) Decomposition of dominant plant species litter in a semi-arid grassland. Appl Soil Ecol 23:13-23

Kuo S (1996) Phosphorus. In: Sparks DL, Page AL, Loeppert PA, Soltanpour PN, Tabatabai MA, Johnston CT et al (eds) Methods of soil analysis Part 3: chemical methods. Soil Science Society of America and American Society of Agronomy, Madison

Li MH, Hoch G, Korner C (2002) Source/sink removal affects mobile carbohydrates in Pinus cembra at the Swiss treeline. Trees-Struct Funct 16:331-337

Li LJ, Zeng DH, Yu ZY, Fan ZP, Yang D, Liu YX (2011) Impact of litter quality and soil nutrient availability on leaf decomposition rate in a semi-arid grassland of Northeast China. J Arid Environ 75:787-792

Li MH, Cherubini P, Dobbertin M, Arend M, Xiao WF, Rigling A (2013) Responses of leaf nitrogen and mobile carbohydrates in different Quercus species/provenances to moderate climate changes. Plant Biol 15:177-184

Liu P, Huang J, Han X, Sun OJ, Zhou Z (2006) Differential responses of litter decomposition to increased soil nutrients and water between two contrasting grassland plant species of Inner Mongolia, China. Appl Soil Ecol 34:266-275

Liu P, Huang J, Sun OJ, Han X (2010) Litter decomposition and nutrient release as affected by soil nitrogen availability and litter quality in a semiarid grassland ecosystem. Oecologia 162:771-780

Liu X, Duan L, Mo J, Du E, Shen J, Lu X, Zhang Y, Zhou X, He C, Zhang F (2011) Nitrogen deposition and its ecological impact in China: an overview. Environ Pollut 159:2251-2264

Ma H, Bai G, Sun Y, Kostenko O, Zhu X, Lin S, Ruan W, Zhao N, Bezemer TM (2016) Opposing effects of nitrogen and water addition on soil bacterial and fungal communities in the Inner Mongolia steppe: a field experiment. Appl Soil Ecol 108: $128-135$

Makkonen M, Berg MP, Handa IT, Hattenschwiler S, van Ruijven J, van Bodegom PM, Aerts R (2012) Highly consistent effects of plant litter identity and functional traits on decomposition across a latitudinal gradient. Ecol Lett 15: 1033-1041

Manning P, Saunders M, Bardgett RD, Bonkowski M, Bradford MA, Ellis RJ, Kandeler E, Marhan S, Tscherko D (2008) Direct and indirect effects of nitrogen deposition on litter decomposition. Soil Biol Biochem 40:688-698

Niu SL, Wu MY, Han Y, Xia JY, Li LH, Wan SQ (2008) Watermediated responses of ecosystem carbon fluxes to climatic change in a temperate steppe. New Phytol 177:209-219

Portillo-Estrada M, Pihlatie M, Korhonen JFJ, Levula J, Frumau AKF, Ibrom A, Lembrechts JJ, Morillas L, Horvath L, Jones SK, Niinemets U (2016) Climatic controls on leaf litter decomposition across European forests and grasslands revealed by reciprocal litter transplantation experiments. Biogeosciences 13:1621-1633

Prescott CE (1995) Does nitrogen availability control rates of litter decomposition in forests. Plant Soil 168:83-88

Schimel J, Balser TC, Wallenstein M (2007) Microbial stressresponse physiology and its implications for ecosystem function. Ecology 88:1386-1394

Schuster MJ (2016) Increased rainfall variability and $\mathrm{N}$ addition accelerate litter decomposition in a restored prairie. Oecologia 180:645-655

Seastedt T (1984) The role of microarthropods in decomposition and mineralization processes. Annu Rev Entomol 29:25-46

Smith VC, Bradford MA (2003) Litter quality impacts on grassland litter decomposition are differently dependent on soil Fauna across time. Appl Soil Ecol 24:197-203

Stump LM, Binkley D (1993) Relationships between litter quality and nitrogen availability in rocky-moutain forests. Can J For Res 23:492-502

Walter J, Hein R, Beierkuhnlein C, Hammerl V, Jentsch A, Schaedler M, Schuerings J, Kreyling J (2013) Combined effects of multifactor climate change and land-use on decomposition in temperate grassland. Soil Biol Biochem 60:10-18

Wang R, Filley TR, Xu Z, Wang X, Li M-H, Zhang Y, Luo W, Jiang Y (2014) Coupled response of soil carbon and nitrogen pools and enzyme activities to nitrogen and water addition in a semi-arid grassland of Inner Mongolia. Plant Soil 381:323-336

Wang X, Xu Z, Yan C, Luo W, Wang R, Han X, Jiang Y, Li M-H (2017) Responses and sensitivity of N, P and mobile carbohydrates of dominant species to increased water, $\mathrm{N}$ and $\mathrm{P}$ availability in semiarid grasslands in northern China. J Plant Ecol. doi:10.1093/jpe/rtw053

Xiao W, Ge X, Zeng L, Huang Z, Lei J, Zhou B, Li M (2014) Rates of litter decomposition and soil respiration in relation to soil temperature and water in different-aged Pinus massoniana forests in the three gorges reservoir area, China. PLoS One 9: e101890

Xu GL, Schleppi P, Li M-H, Fu SL (2009) Negative responses of Collembola in a forest soil (Alptal, Switzerland) under experimentally increased N deposition. Environ Pollut 157: 2030-2036

Xu Z, Wan S, Zhu G, Ren H, Han X (2010) The influence of historical land use and water availability on grassland restoration. Restor Ecol 18:217-225

Xu GL, Kuster TM, Guenthardt-Goerg MS, Dobbertin M, Li M-H (2012a) Seasonal exposure to drought and air warming affects soil Collembola and mites. PLoS One 7:e43102 
Xu ZW, Wan SQ, Ren HY, Han XG, Li MH, Cheng WX, Jiang Y (2012b) Effects of water and nitrogen addition on species turnover in temperate grasslands in northern China. PLoS One 7:e39762

Xu ZW, Wan SQ, Ren HY, Han XG, Jiang Y (2012c) Influences of land use history and short-term nitrogen addition on community structure in temperate grasslands. J Arid Environ 87: 103-109

Yue K, Yang W, Peng C, Peng Y, Zhang C, Huang C, Tan Y, Wu F (2016) Foliar litter decomposition in an alpine forest meta- ecosystem on the eastern Tibetan plateau. Sci Total Environ 566-567:279-287

Zhang D, Hui D, Luo Y, Zhou G (2008) Rates of litter decomposition in terrestrial ecosystems: global patterns and controlling factors. J Plant Ecol 1:85-93

Zhu W, Wang J, Zhang Z, Ren F, Chen L, He JS (2016) Changes in litter quality induced by nutrient addition alter litter decomposition in an alpine meadow on the Qinghai-Tibet plateau. Sci Rep-UK 6:34290 